\title{
Using service-learning approach for promoting higher order thinking skills among Pakistani pre-service teachers
}

\author{
Muhammad Saeed*1 | Iqbal Ahmed ${ }^{2}$ \\ 1. Department of Global Studies, King Fahd University of Petroleum \& Minerals, Saudi Arabia. \\ 2. Department of Education, University of Malakand, Chakdara, Dir Lower, Pakistan.
}

*Corresponding Author Emails: msaeedpk@kfupm.edu.sa | saeeddir@gmail.com

Published: November 9, 2021

\begin{abstract}
Modern educational pedagogies emphasize that teaching and learning frameworks should be designed to promote essential skills among students and develop their higher order thinking skills and the real-world application of those skills. In this milieu, service-learning is an emerging approach in education that best meets this need. Although much work exists on service-learning in developing students' social, moral, and citizenship potential, there is a lack of research that highlights the role of service-learning and its potential to promote high order thinking skills among pre-service teachers. This study attempts to extensively examine the role of service-learning in promoting high-order thinking skills among pre-service teachers. For this purpose, an integrated approach of Queensland University's higher order thinking guidelines was compared and contrasted as a framework with service-learning approach. The analysis and literature review showed that said the guidelines can be adopted using service-learning approach to promote higher order thinking skills of pre-service teachers. Therefore, the framework is proposed to be integrated into a service-learning course in higher education. The guidelines provide a five steps process for developing higher order thinking skills among teacher education students. The study results provide teacher educators with more practical ways to implement a more active and purposeful teaching and learning environment that encourages higher order thinking among pre-service teachers.
\end{abstract}

Keywords: service-learning, thinking skills, higher order thinking skills, pre-service teachers, higher education integrated approach, active learning, real word application.

How to Cite: Saeed, M., \& Ahmed. I (2021). Using service-learning approach for promoting higherorder thinking skills among Pakistani pre-service teachers, Pakistan. Journal of Humanities, Social and Management Sciences (JHSMS), 2(1), 187-199. https://doi.org/10.47264/idea.jhsms/2.1.16

Publisher's Note: IDEA PUBLISHERS (IDEA Journals Group) stands neutral regarding jurisdictional claims in the published maps and institutional affiliations.

Copyright: ( 2021 The Author(s), published by IDEA PUBLISHERS (IDEA Journals Group).

Licensing: This is an Open Access article published under the Creative Commons AttributionNonCommercial 4.0 International License (http://creativecommons.org/licenses/by-nc/4.0/) 
Using service-learning approach for promoting higher order thinking skills among Pakistani ...

\section{Introduction}

Service-leaning is a credit-bearing and course that integrates meaningful community service with instruction and reflection to enrich the learning experience, teach collaboration and civic responsibility (Butin, 2010). As an experiential teaching-learning approach, service-learning focuses on active learning and discourages rote learning and passive listening. Higher order thinking skills include critical thinking, deep analysis, synthesis, reflection, and creative writing. These skills are in great demand nowadays in all teacher training programs. In recent decades, a significant shift has occurred in teacher education. This shift is towards active and participative learning rather than dictation and isolation. In many parts of the world, this shift has already taken place. Teachers increasingly use this approach to help students learn leadership and critical thinking skills by contributing more actively rather than only receiving the new information as customers. It shows an emphasis on using, managing, and applying the knowledge rather than storing it. The other significant stress is enjoying the learning experience rather than making it a routine for themselves (Eyler \& Jr. Giles, 1999; Wurr \& Hamilton, 2012). Research suggests that participation in the high order thinking skills activity, students at higher education institutions pose arguments, state opinions, look for more evidence, critique the evidence and think with open-mindedness (Amtmann, 2004; Anson, 1997).

\section{Service-learning approach}

Service-learning is currently emerging as an active and experiential approach that helps students develop their high order thinking by acquiring information through explorations and using it based on reflections and its applicability in different situations (Eyler \& Jr. Giles, 1999; Butin, 2010). Service-learning is an active learning approach that stresses critiquing, creating, using, exploring, and sharing experiences and knowledge rather than storing it passively. As an operational learning strategy, service-learning helps students think about what they are doing due to a service activity (Bamber \& Hankin, 2011). Researchers have indicated that all active learning approaches support students to learn more and retain the new knowledge that they acquire as a result of reflection and application of the information in a new context rather than storing it in a passive manner (Butin, 2006; Levesque-Bristol et al., 2010). Studies have also suggested that for enhancing the learning experience, it is essential that teachers of higher education institutions should prioritize gathering of information and ideas by students through critical thinking, knowledge, reflection, and direct experience outside of their traditional classroom environment (Celio et al., 2011). Service-learning best meets this criterion that can be used as a critical pedagogy to promote students' higher-order thinking skills at the higher education level. It is based on experience, reflection, and applying new knowledge in a situation where people collaborate to solve their problems. Higher education institutions can use this strategy more effectively by either integrating it as a curricular or co-curriculum tool to develop students higher order thinking skills (Holmes, 2013; Zlotkowski, 1998).

The universities are fast prioritizing higher order thinking skills as the main academic targets. For example, higher education institutions in the United States have always tried to excel in the race for skills development. As a result, the country stands among the top countries globally to hold a higher position in employees having high job-related skills. The earlier aims of the universities and colleges were to develop the life skills of people to make them engaged citizens (Ash \& Clayton, 2004; Strouse, 2003; Wade, 2007). To achieve this exalted aim, the universities and colleges adopted intensive service-learning programs from the 1960s. Since 
then, service-learning has been flourishing in the United States. Service-learning is used as a mechanism for community engagement high-impact pedagogy across higher education institutions to promote students higher order thinking skills such as reflection, analysis, evaluation, and synthesis. It has been observed that as an active and experiential teaching and learning approach, service-learning provides suitable and extensive opportunities for students to develop these academic abilities. For the reflection, it must take both oral and written forms. However, it can be undertaken individually and collectively. Critical reflection is one of the essential components of service-learning that develops and promotes students higher order thinking skills. It deepens, generates, and enhances more active learning (Ash et al., 2005).

As a teaching and learning strategy, service-learning extensively promotes academic engagement and performance of students in higher education (Buch \& Harden, 2011; Heffernan, 2011).Research has shown that participating in high-quality service-learning produces better results in attendance, grades, and higher problem-solving skills. These skills are related to students' competencies in different areas such as language, math, science, and social studies (Butin, 2010; Calvert, 2012). Studies suggest that nowadays, higher education institutions have focused the successful implementation of service-learning leads to better thinking skills of students. For this purpose, teachers and administrators are devising different programs to provide students with an active and student-centered learning environment. Further, studies show that students with a collaborative and experiential learning environment open vistas of opportunities to apply their thinking skills in solving problems they face (Battistoni et al., 2009; Beyte \& Farr, 1997). On the other hand, there are apprehensions that in many parts of the world, at higher education institutions, still, teachers at higher education level use the traditional teaching and learning strategies such as lectures and rote learning that narrows down the potentials to grow intellectually and socially (Butin, 2005).

It is believed that teachers are either unaware of the different modern active teaching methods or feel uncomfortable using such techniques during the teaching process (Calvert, 2012). However, studies have revealed that such issues can be overcome by planning and using creative and active pedagogies such as program learning and service-learning (Strouse, 2003; Zhang et al., 2011). However, these education methods are a bit expensive and timeconsuming, but they are effective ways and strategies to promote higher order thinking among students at higher education levels. The main objectives of this paper are, to analyze the existing situation and propose a model of high order thinking skills at the higher education level. The rationale for choosing this problem is that it will be highly beneficial to students, teachers, administrators of higher education institutions. It may also help achieve $21^{\text {st }}$ Century higher order skills development focused by higher education institutions around the world. Furthermore, researchers believe that to make learning more active, there is a need to use more collative, creative, and dynamic teaching and learning strategies. For students to participate and enhance their higher order thinking, it is vital that they state their opinions freely, narrate their own experiences, share their views, and critique others' opinions with evidence using primary and secondary sources of information effectively. For this purpose, research has emphasized devising creative and participative teaching and learning activities that motivate them to think critically (Heffernan, 2011; Scheuermann, 1996).

\section{Service-learning and higher order thinking skills}

This paper shows that service-learning experiences can be designed and developed based on a 
Using service-learning approach for promoting higher order thinking skills among Pakistani ...

simple framework. The service-learning can be used to develop higher order thinking skills of students in higher education (Aberle-Grasse, 2000). The main aim of service-learning itself is to build students' academic knowledge, skills, and knowledge dispositions. Developing critical thinking or higher order thinking is often an explicit goal of service-learning (Rahman et al., 2011). Well-designed service-learning activities motivate students to evaluate different perspectives and complex issues. This will help students to develop their thinking critically and to understand the social problems in society. In another study, Eyler and Jr. Giles (1999) found that service-learning increasingly enhances students' reasoning capacities. They successfully apply their newly gained knowledge in new situations, which is impossible in a traditional teaching and learning environment where students merely receive and store knowledge or information. Participation in a well-designed service-learning program is a precise predictor of deeper thinking and increased reflections over the complexity of issues and analysis of situations to present solutions to different problems of society. Drawing on the cognitive theory, service-learning helps explain the pedagogy and its ability to promote students' intellectual growth, which is one of higher education goals. Service-learning fundamentally encourages the students to read different situations from varying perspectives on their own independently. This helps them cultivate and promote their capacities to make informed judgments in various matters related to people's lives in society (Eyler \& Jr. Giles, 1999; Rahman et al., 2011).

There is an emerging consensus among scholars about the suitability of service-learning for cultivating higher order reasoning of students and their critical thinking skills (Ash et al., 2005). In critical thinking, reflection plays a key role by connecting academic content with real-life situations and learning objectives. To promote students higher order thinking skills, servicelearning educators take help from Bloom's taxonomy and Paul and Edler's (206) standards for critical thinking. This helps the students to focus areas through critical thinking like civic learning and personal growth. In the process of reflection and critical thinking, students may need scaffolding and guided practice for moving beyond the course concept only such a critical evaluation of such ideas and their application in real-life situations. In this way, students often may need to learn from various sources through critical reflection. This develops their capacities for higher order reasoning and critical thinking. Another study demonstrated that, among other abilities, service-learning also improved students' connectedness to the communities and life skills (Ash et al., 2005; Astin \& Astin, 2000). Apart from acquiring the core knowledge and skills, some scholars have found that service-learning helped improved students higher order thinking skills such as analysis, problem-solving, decision-making, cognitive complexities, and inferential comprehension. Students are extensively exposed to different challenging tasks requiring such skills to deal with the problems during servicelearning. In this scenario, teachers play a pivotal role in facilitating dialogue and understanding more complex issues. For example, students during service-learning provide service to communities, help homeless people. Thus, students are more likely to improve their higher order skills if teachers facilitate discussions on different critical social, political, and economic issues (Astin \& Sax, 1998; Vogelgesang \& Astin, 2000).

\section{High order thinking skills}

One of the aims of education is developing the critical thinking of students. This higher order type of thinking allows the students to excel in all fields of education and attain intellectual freedom. Thinking is the cognitive process where students try to make sense of their world, 
question everyday assumptions which direct their thinking and behavior. The primary purpose of this paper is to enable students to develop higher order thinking skills necessary for leading a successful life (Bowen, 2007). Higher education institutions are industries that produce human capital. Active learning provides a supportive environment that is enjoyable and useful for students, institutions, and societies alike. For this to happen, the researchers suggest that higher education educators should give up the belief that students would not be able to cover up the subject unless the teacher 'covers it' up. As a result of providing students with an active teaching and learning atmosphere, students may get some exposure to the materials via preclass reading and lectures (Eyler, 1997; Giles \& Eyler, 1994). However, most researchers believe that practical understanding of the material occurs when they are collaboratively and actively engaged in learning experiences and reflect on the meaning of what they do (Butin, 2006; Cruz \& Giles, 2000). Higher order thinking skills are those skills that students acquire as a result of critical thinking and reflections. These skills include a consideration, critiquing, evaluation, analysis, and so on. These skills are today's most coveted and cherished by employers, organizations, and societies to be present among students. To develop such skills in students, teachers must add experiential learning opportunities for students.

Additionally, more profound reflections also help students develop such skills. It is argued that students may develop such skills if they actively participate in the learning experience. They should be able to reflect and critique with evidence the situation. This must be supported by primary and secondary sources (Abedini et al., 2012). Some writers suggest more and more practice as an essential element of critical thinking that lays the foundation for higher order thinking skills (Ahmad et al., 2014). Higher education is a stage where students become intellectually mature. Through practice, they attain intellectual freedom, which is one of the primary goals of higher education. Thinking is a cognitive process that involves questioning and critiquing. The method of questioning directs students to look for new solutions that can positively impact the quality of their lives. It is argued that for quality life, practical thinking skills are a must. Through deeper thinking, students get more practical exposure to the material at hand as compared to lectures. This leads to a proper understanding of the material when actively involved with and reflecting on it. Furthermore, they successfully get meaning from the material due to deeper thinking, which is impossible when they listen through lectures (Bringle \& Clayton, 2012).

\section{Service-learning project}

This paper proposes five effective ways to promote effective high-order thinking for teacher education courses using service-learning as a platform or strategy. The service-learning cycle occurs in five steps:

- Problem identification: In this stage, students are involved in exploring issues in a community that needs prompt solutions. For example, they go to the community site and identify the problem after interacting with them.

- Planning and designing: In this stage, the students decide how to solve the problem and choose the necessities.

- Application and implementation: In this stage, the students go to the site and perform the service. For example, they work with the community people.

- Collaboration and coordination: At this stage, the students work in reciprocity with the community people and solve the problem. 
Using service-learning approach for promoting higher order thinking skills among Pakistani ...

- Reflection: It is the most critical stage where students reflect on the service they have provided. This helps them learn about the impact of the service they provide to the community.

Based on the above-mentioned theoretical foundation, this paper uses the five essential steps suggested and proposed by the Queensland Government in 2002necessaryfor promoting higher thinking skills among students. These guidelines are also in line with the suggestions of servicelearning theorists. For example, the steps fully comply with David Kolb's learning cycle. He proposes that active learning occurs in different stages such as concrete experience, reflective observation, abstract conceptualization, and active experimentation. It also matches with Asin's student involving developmental theory in higher education in which he explains how students change and develop as a result of practical involvement in activities. The theory further explains that it is vital to get input from students related to their previous experiences. In his view, the environment is essential to students in the education institutions during the study period. The desired outcomes must be focused on what students demonstrate in the form of knowledge, skills, and attitudes in practical life. He also provides five critical assumptions about the involvement of students in learning. According to him, involvement needs psychosocial and physical energy as a first step. Secondly, it should be continuous; thirdly, involvement should be qualitative as well as quantitative. Fourth, identification of the level of participation, and lastly, academic performance and its implications. The service-learning cycle also emphasizes these grounds. The service-learning process starts with observation (preservice), analysis (during the service), evaluation, and new understanding (after service).

After being incorporated in a service-learning course, the proposed guidelines may help teacher education students at the higher education level improve their high-order thinking skills. These thinking skills can be implemented in any teaching and training program as a foundation of an active learning environment and art of higher order thinking. The following five-step process for developing higher order thinking can be utilized by using service-learning as a vibrant learning environment. This may move push learners' higher order thinking. Figure 1 shows the process for developing high-order-level thinking skills.

Figure 1: Process for developing high-order-level thinking skills

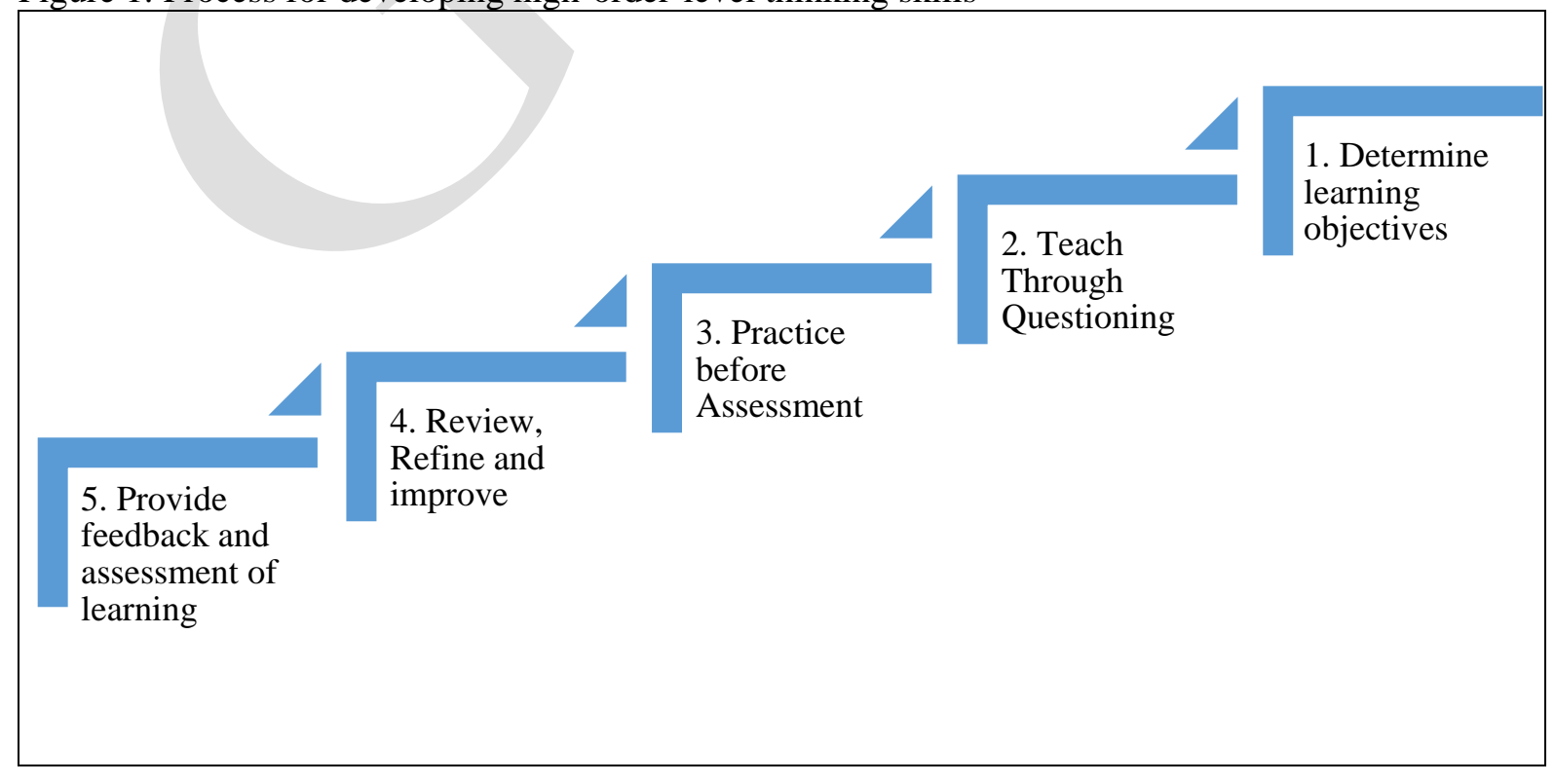


The five steps mentioned above present the process for developing higher order thinking skills among students using service-learning as an approach. This framework has been adopted from Queensland University's higher order thinking guidelines (Limbach \& Waugh 2010). The models fit the service-learning goals, which include exploration, application, reflection, and feedback for improvement. Service-learning is a critical and active pedagogy that provides ample opportunities for students to apply their knowledge in new life situations. It also helps students promote their higher order thinking skills through experience, reflection, analysis, and evaluations. The five-step process is discussed in the subsequent sections as follow:

\subsection{Determine learning objectives}

Determination of learning objectives is essential for placement of the program providing a solid base for knowledge development. Service-learning as pedagogy emphasizes knowledge exploration based on key objectives (Calvert, 2012). Service-learning instructors should identify key learning objectives for recognizing what students should know, have specific skills, and demonstrate and apply those skills in real-life situations when they exit a program. The service-learning teachers should also try to determine objectives that should help them design experiential learning activities and assessments requiring students to perform and demonstrate high order thinking. A sound goal always stresses behavior, knowledge, and skills appropriate for the thinking faculty improvement of students. In this regard, the teachers can utilize the revised levels of Bloom's taxonomy for curriculum planning and implementation (Bringle et al., 2004). The revised taxonomy, such as remember, understand, apply, analyze, evaluate, and create shown in Figure 2 and 3, clearly align standards and educational goals and objectives. Developing well-written objectives increases the learners' motivation for higher order thinking (Ali et al., 2012).

\section{Figure 2: Bloom's Taxonomy- Cognitive Domain (2001)}

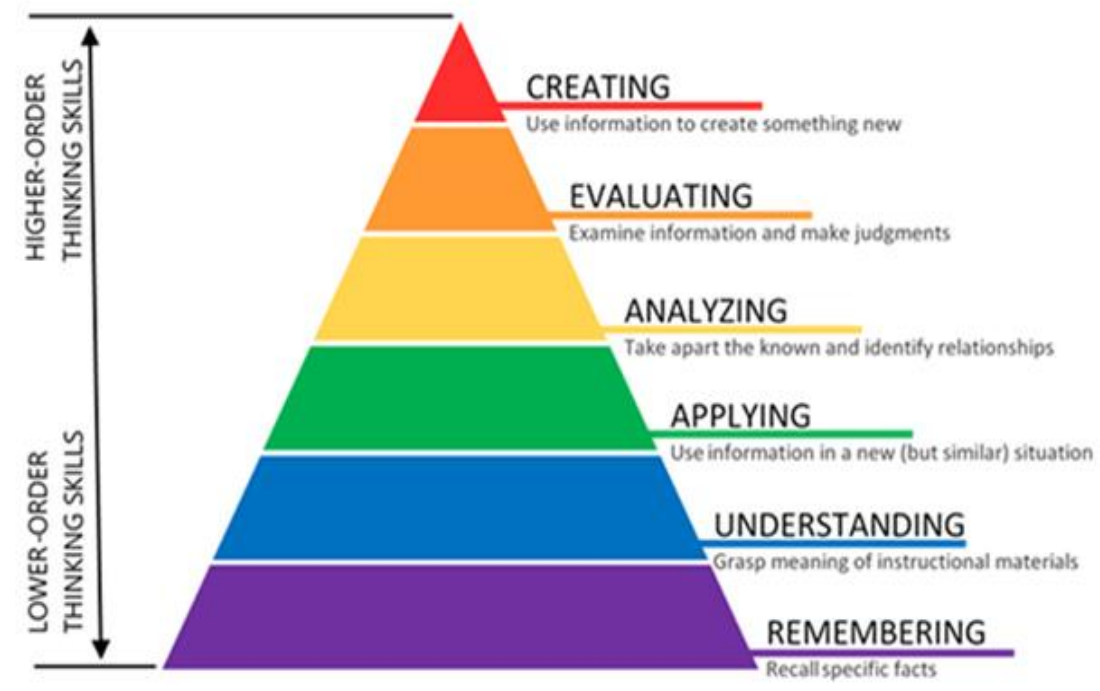

Source: https://citt.ufl.edu/resources/the-learning-process/designing-the-learning- 
Using service-learning approach for promoting higher order thinking skills among Pakistani ...

Figure 3: Bloom Taxonomy: Action Verbs and Activities

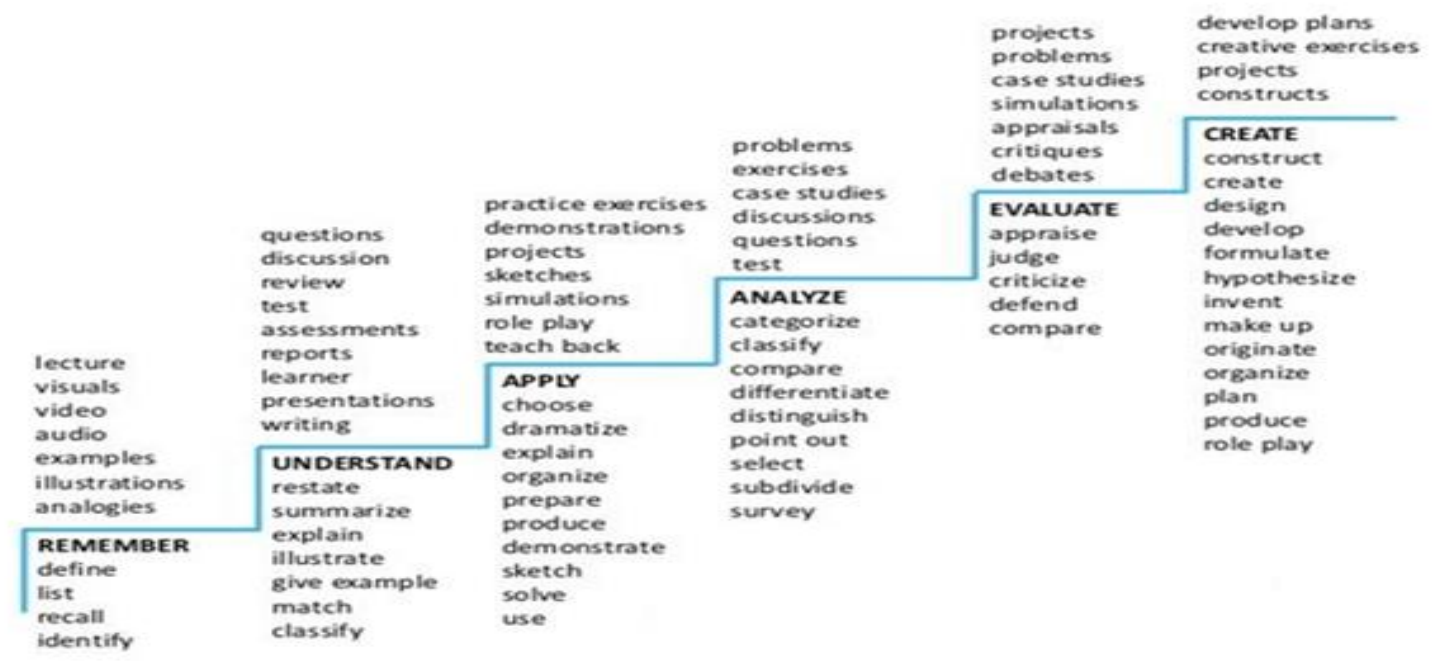

Source:

Bloom Taxonomy Action Verbs and Activities by fida Hokkanen is lifoensed under a

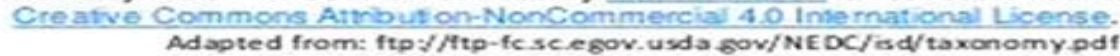

\subsection{Teaching through questioning}

Questioning is vital in teaching and learning. Questions enable students and teachers to go beyond the material, creating a new vision and ideas. Service-learning is an active pedagogy that stresses creating new knowledge using reflection as a basis for questioning. Students' higher order thinking flourishes when teachers provide students with such opportunities where they find the information and critique it by reflection and questioning (Harkavy \& Hartley, 2010). Teachers must know the purpose of each question and develop an appropriate level of questioning to enable the students to be familiar with the concept. As a result, the students will develop the required level of thinking to accomplish the purpose. This will provide the students such experiences that will promote the higher-level questioning when they become familiar with the concepts. So both types of questions, such as divergent and convergent questions, can be covered by applying Bloom's levels of applying and creating (Weigert, 1998). This ultimately contributes towards the development of higher order thinking among students. Therefore, it is suggested that teachers should use questioning techniques to inspire higher order thinking among students. For this purpose, they may develop appropriate questions, employ questioning techniques, and encourage interactive discussions.

\subsection{Practice before assessment}

For effective teaching and learning, teachers are required to develop experiential learning and opportunities using reflection and critical thinking as a foundation. Students need to pose arguments, give opinions, and critique evidence using primary and secondary sources (Balazadeh, 1996). Service-learning as a critical pedagogy enables students to reason, reflect and critique in the process of learning. It is believed that practice is the foundation of skills development. It is advised that during service-learning activity, teachers need to provide 
students high effective and structured learning opportunities for practicing and evaluating knowledge, skills, behaviors, and attitudes. For this purpose, teachers should design multiple assessments and evaluation programs to assess students' learning and development. Allowing students to self-evaluate their learning and development is another step that is key to developing higher thinking (Ash \& Clayton, 2004).In the current times, a significant shift has occurred in education, i.e., towards active learning. To develop higher thinking among students, they must pose arguments, state opinions, look for evidence, critique evidence, and think fairly and open-mindedly. When students and teachers believe what should happen and what should not, they should encourage higher order thinking. Service-learning teachers typically manage to collect information and ideas, experiences, and reflections. Therefore, teachers in higher education must design active learning experiences for students with some experiential learning and opportunities for creating a complete set of learning activities. The scope of experiential learning can also be enhanced by including direct experiences and reflections (Finkel \& Smith, 2011). The information and ideas must be based on outside class experiences, e-observing, online learning, simulations, papers, portfolios, and journaling. The direct experiences through service-learning must also include direct observations, reflective thinking, service-learning journaling, and dialogue (Carrington \& Selva, 2010).

\subsection{Review, refine and improve}

For developing higher order thinking of students, teachers must ensure that the instructional techniques are in line with the critical thinking goals of the education system. Service-learning provides students ample opportunities to become responsible for their knowledge. During the process of service activity, teachers effectively monitor the class activities, create a supportive environment, and engage students actively in the process of learning (Crossman \& Kite, 2007). This typically does not happen in a traditional class environment. It is advised that teachers must provide timely feedback to students. To develop students higher order thinking, teachers must create a conducive environment for discussions that promotes students higher order thinking skills. Teachers also need to monitor the classroom activities for tracking student participation closely. For this purpose, teachers may keep a diary. Student feedback may also be used for course improvement and success. Along with teacher feedback, students can also become their monitors and monitor their learning. In this way, they assess their understanding and change their study timing and skills to improve their courses' success (Welch, 1999; Welch \& James, 2007).

\subsection{Provide feedback and assessment of learning}

Teachers need to provide assessment, feedback and also compare the criteria and standards for students' performance. It is also advisable that students be provided with constructive and relevant feedback by teachers and peers (Slivovsky et al., 2004). Students and teachers provide assessment and critical feedback during service-learning to evaluate instructional techniques and learning activities. It is necessary that the quality of student learning and performance rather than the grading of students' performance. Feedback allows students to learn how to assess their performance in the future. There is a need to successful performance from unsuccessful performance as they discuss criteria and standards. Teachers need to provide effective feedback through frequent practice and also provide assessment time to students. For this purpose, teachers should give ample time to help students understand the criterion and standards. In this regard, students provide feedback and evaluation (Ash \& Clayton, 2004). 
Using service-learning approach for promoting higher order thinking skills among Pakistani ...

\section{Conclusion}

Based on this review, it can be concluded that service-learning is a unique power to cultivate teacher education students' critical thinking skills in higher education. It challenges traditional teaching and learning activities and calls on teachers and students to consume knowledge and produce it. The review concludes that the goals of developing teacher education students' higher order thinking skills can be promoted by designing higher-scale service-learning projects. The research concludes that service-learning is a transformative learning approach that changes students' frame of seeing the world around them in a critical way by critically reflecting on it. The research further concludes that service-learning as an active pedagogy provides students wider opportunities to critically investigate their assumptions, beliefs, and understanding of the world. The paper concludes that service-learning can develop student's capacities to engage as active partners and critical friends. The study further provides the insight that the capacity of service-learning as a vibrant and transformative pedagogy can be enhanced when it positions students as co-learners, co-educators, and co-generators of knowledge rather than merely storing the information through memorization. Finally, based on this research review, it can be argued that service-learning qualifies as a critical and active pedagogy that promotes students high order thinking skills in higher education.

\section{References}

Abedini, N. C., Gruppen, L. D., Kolars, J. C., \& Kumagai, A. K. (2012). Understanding the effects of short-term international service-learning trips on medical students. Academic Medicine, 87(6), 820-828. https://journals.lww.com/academicmedicine/Fulltext/2012/06000/Understanding th e_Effects_of_Short_Term.29.aspx

Aberle-Grasse, M. (2000). The Washington study-service year of Eastern Mennonite University reflections on 23 years of service learning. American Behavioral Scientist, 43(5), 848-857. https://doi.org/10.1177/00027640021955504

Ahmad, I., Said, H., Mansor, S. S. S., Mokhtar, M., \& Ghani, F. A. (2014). Role of reflection in moderating the relationship between service-learning and civic development. Review of European Studies, 6(3), 74. https://doi.org/10.5539/res.v6n3p74

Ali, H. O., Rahman, A. A., \& Abidin, W. Z. (2012). Service learning: An investigation into its viability as a strategy to achieve institutional goals. Procedia-Social and Behavioral Sciences, 56, 388-395. https://doi.org/10.1016/j.sbspro.2012.09.667

Amtmann, J. (2004). Perceived effects of a correctional health education service-learning program. Journal of Correctional Education, 335-348. https://www.jstor.org/stable/23292098

Anson, C. M. (1997). On reflection: The role of logs and journals in service-learning courses. Writing the community: Concepts and models for service-learning in composition, 167-180. https://files.eric.ed.gov/fulltext/ED449729.pdf

Ash, S. L., \& Clayton, P. H. (2004). The articulated learning: An approach to guided reflection and assessment. Innovative Higher Education, 29(2), 137-154. https://scholarworks.iupui.edu/bitstream/handle/1805/9644/The\%20Articulated\%20 Learning\%20\%20An\%20Approach\%20to\%20Guided \%20Reflection\%20and $\% 20$ Assessment $\% 2$ $0-\% 20 \mathrm{Ash} \% 20$ and $\% 20$ Clayton.pdf; sequence $=1$ 
Ash, S. L., Clayton, P. H., \& Atkinson, M. P. (2005). Integrating reflection and assessment to capture and improve student learning. Michigan Journal of community service learning, 11(2), 49-60. http://hdl.handle.net/2027/spo.3239521.0011.204

Astin, A. W., \& Astin, H. S. (2000). Leadership reconsidered: Engaging higher education in social change. https://digitalcommons.unomaha.edu/slcehighered/133/

Astin, A. W., \& Sax, L. J. (1998). How undergraduates are affected by service participation. Journal of College Student Development, 39, 251-263. https://digitalcommons.unomaha.edu/cgi/viewcontent.cgi?article $=1012 \&$ context $=\mathrm{s} 1$ cehighered

Balazadeh, N. (1996). Service-Learning and the sociological imagination: Approach and assessment. https://eric.ed.gov/?id=ED402854

Bamber, P., \& Hankin, L. (2011). Transformative learning through service-learning: No passport required. Education+ Training, 53(2/3), 190-206. https://doi.org/10.1108/00400911111115726

Battistoni, R. M., Longo, N. V., \& Jayanandhan, S. R. (2009). Acting locally in a flat world: Global citizenship and the democratic practice of service-learning. Journal of Higher Education Outreach and Engagement, 13(2), 89-108. https://files.eric.ed.gov/fulltext/EJ905398.pdf

Beyte, H. G., \& Farr, J. (1997). The work of citizenship and the problem of service-learning. American Association for Higher Education, Washington DC https://digitalcommons.unomaha.edu/cgi/viewcontent.cgi?article=1000\&context=sl ceciviceng

Bowen, G. (2007). Reflection in service learning. University of Nebraska at Omaha. https://digitalcommons.unomaha.edu/cgi/viewcontent.cgi?article $=1023 \&$ context $=$ sl ceeval

Bringle, R. G., \& Clayton, P. H. (2012). Civic education through service learning: What, how, and why?. In Higher Education and Civic Engagement (pp. 101-124). Palgrave Macmillan. https://link.springer.com/chapter/10.1057/9781137074829_7

Bringle, R. G., Phillips, M. A., \& Hudson, M. (2004). The measure of service learning: Research scales to assess student experiences. American Psychological Association, Washington

$D C$. https://citeseerx.ist.psu.edu/viewdoc/download?doi=10.1.1.508.6700\&rep=rep1\&ty pe $=$ pdf

Buch, K., \& Harden, S. (2011). The impact of a service-learning project on student awareness of homelessness, civic attitudes, and stereotypes toward the homeless. Journal of Higher Education Outreach and Engagement, 15(3), 45-61. https://files.eric.ed.gov/fulltext/EJ945478.pdf

Butin, D. W. (2005). Service-learning as postmodern pedagogy. In Service-learning in higher education (pp. 89-104). Palgrave Macmillan. https://link.springer.com/chapter/10.1057/9781403981042_6

Butin, D. W. (2006). The limits of service-learning in higher education. The Review of Higher Education, 29(4), 473-498. https://citeseerx.ist.psu.edu/viewdoc/download?doi=10.1.1.392.9924\&rep=rep1\&ty pe $=$ pdf

Butin, D. W. (2010). Service-learning in theory and practice: The future of community engagement in higher education. Palgrave Macmillan.

Calvert, V. (2012). Developing Leaders through Service-Learning: A Canadian Experience. Journal of Higher Education Theory and Practice, 12(5), 60-73. 
Using service-learning approach for promoting higher order thinking skills among Pakistani ...

https://www.academia.edu/48223196/Developing_Leaders_through_Service_Learni ng_A_Canadian_Experience

Carrington, S., \& Selva, G. (2010). Critical social theory and transformative learning: Evidence in pre-service teachers' service-learning reflection logs. Higher Education Research \& Development, 29(1), 45-57. https://doi.org/10.1080/07294360903421384

Celio, Durlak, \& Dymnicki. (2011). A meta-analysis of the impact of service-learning on students. Journal of Experiential Education, 34(2), 164-181. https://doi.org/10.1177/105382591103400205

Crossman, J. M., \& Kite, S. L. (2007). Their perspectives: ESL students' reflections on collaborative community service learning. Business Communication Quarterly, 70(2), 147-165. https://doi.org/10.1177/1080569907301776

Cruz, N. I., \& Giles, D. (2000). Where's the community in service-learning research. Michigan Journal of Community Service Learning, 7(1), 28-34. http://hdl.handle.net/2027/spo.3239521.spec.104

Eyler. (1997). Service-learning and the development of expert citizens. https://eric.ed.gov/?id=ED408506

Eyler, J., \& Jr. Giles, D. E. (1999). Where's the learning in service-learning? Jossey-Bass Higher and Adult Education Series. https://eric.ed.gov/?id=ED430433

Finkel, S. E., \& Smith, A. E. (2011). Civic education, political discussion, and the social transmission of democratic knowledge and values in a new democracy: Kenya 2002. American Journal of Political Science, 55(2), 417-435. https://doi.org/10.1111/j.15405907.2010.00493.x

Giles, \& Eyler. (1994). The theoretical roots of service-learning in John Dewey: Toward a theory of service-learning. Michigan Journal of Community Service Learning, 1(1), $77-85$.

https://digitalcommons.unomaha.edu/cgi/viewcontent.cgi?article=1152\&context=sl ceslgen

Harkavy, I., \& Hartley, M. (2010). Pursuing Franklin's dream: Philosophical and historical roots of service-learning. American Journal of Community Psychology, 46(3-4), 418427.https://www.aacu.org/publications-research/periodicals/pursuing-franklinsdemocratic-vision-higher-education

Heffernan, K. (2011). Service-learning in higher education. Journal of Contemporary Water $\begin{array}{lll}\text { Research } & \text { Education, } & \end{array}$ https://opensiuc.lib.siu.edu/cgi/viewcontent.cgi?article=1160\&context=jcwre

Holmes. (2013). An exploration of misslw school teachers' essences of partcipation in servicelearning activities. University of Central Missouri. http://hdl.handle.net/10355/37831

Levesque-Bristol, C., Knapp, T. D., \& Fisher, B. J. (2010). The effectiveness of servicelearning: it's not always what you think. Journal of Experiential Education, 33(3), 208-224. https://doi.org/10.1177/105382590113300302

Rahman, M. F., Babu, R., \& Ashrafuzzaman, M. (2011). Assessment and feedback practices in the english language classroom. Journal of NELTA, 16(1-2), 97-106. https://doi.org/10.3126/nelta.v16i1-2.6133

Scheuermann, C. D. (1996). Ongoing cocurricular service-learning. In B. Jacoby, \& Associates (Eds.), Service-learning in higher education: Concepts and practice (pp. 135-155). Jossey-Bass.

Slivovsky, L. A., Jr. De Rego, F. R., Zoltowski, C. B., Jamieson, L. H., \& Oakes, W. C. (2004). An analysis of the reflection component in the epics model of service learning. Paper presented at the Proceedings of the American Society for Engineering Education 
Annual Conference and Exposition, Salt Lake, UT. https://digitalcommons.unomaha.edu/slceeval/54

Strouse, J. H. (2003). Reflection as a service-learning assessment strategy. Journal of Higher Education Outreach and Engagement, 8(2), 75-87. https://ojs01.galib.uga.edu/jheoe/article/view/618

Vogelgesang, L. J., \& Astin, A. W. (2000). Comparing the effects of community service and service-learning. Michigan Journal of Community Service Learning, 25-34. http://hdl.handle.net/2027/spo.3239521.0007.103

Wade. (2007). Service-learning for social justice in the elementary classroom: Can we get there from here? Equity \& Excellence in Education, 40(2), 156-165. https://doi.org/10.1080/10665680701221313

Weigert, K. M. (1998). Academic service learning: Its meaning and relevance. New directions for teaching and learning, 1998(73), 3-10. https://doi.org/10.1002/TL.7301

Welch, M. (1999). The ABCs of reflection: A template for students and instructors to implement written reflection in service-learning. NSEE quarterly, 25(2). https://digitalcommons.unomaha.edu/cgi/viewcontent.cgi?article $=1031 \&$ context $=\mathrm{s} 1$ ceeval

Welch, M., \& James, R. C. (2007). An investigation on the impact of a guided reflection technique in service-learning courses to prepare special educators. Teacher Education and Special Education: The Journal of the Teacher Education Division of the Council for Exceptional Children, 30(4), 276-285. https://doi.org/10.1177/088840640703000407

Wurr, A. J., \& Hamilton, C. H. (2012). Leadership development in service-learning: An exploratory investigation. Journal of Higher Education Outreach and Engagement, 16(2), 213-240. https://files.eric.ed.gov/fulltext/EJ975818.pdf

Zhang, G., Zeller, N., Griffith, R., Metcalf, D., Williams, J., Shea, C., \& Misulis, K. (2011). Using the context, input, process, and product evaluation model (CIPP) as a comprehensive framework to guide the planning, implementation, and assessment of service-learning programs. Journal of Higher Education Outreach and Engagement, 15(4), 57-84. https://files.eric.ed.gov/fulltext/EJ957107.pdf

Zlotkowski, E. (1998). Successful service-learning Programs. New Models of Excellence in Higher Education. https://eric.ed.gov/?id=ED419453 